\title{
Effects of modulation dietary gelatinized cornstarch/protein ratio on growth performance, feed utilization, and body composition of tilapia Oreochromis niloticus fingerlings
}

\author{
Y E O Gopéyué Maurice ${ }^{1,2}$, B L E Mélécony Célestin ${ }^{1 *}$, Fagbohoun Bédel ${ }^{2}$, Etchian Assoi Olivier³, Dabonne Soumaila ${ }^{2}$ \\ 'Département Aquaculture, Centre de Recherches Océanologiques, BP V 18 Abidjan, Côte d’Ivoire. ${ }^{2}$ Département des Sciences et Technologies des Aliments, \\ Laboratoire de Biocatalyse et des Bioprocédés, Université Nangui Abrogoua, 02 BP 801 Abidjan 02, Côte d'Ivoire. ${ }^{3}$ Laboratoire de Biologie et Cytologie \\ Animales, UFR-SN, Université Nangui Abrogoua, 02 BP 801 Abidjan 02, Côte d'Ivoire.
}

\section{ARTICLE INFO \\ Article history: \\ Received on: January 16, 2018 \\ Accepted on: April 04, 2018 \\ Available online: August 01, 2018}

Key words:

Oreochromis niloticus, Gelatinized cornstarch,

Protein,

Feed utilization,

Growth.

\begin{abstract}
A 56-day feeding experiment was conducted to determine the effects of modulated dietary gelatinized maize starch with protein level on the growth and feed utilization of juvenile Oreochromis niloticus. Four experimental diets (G16P28, G21P26, G26P23, and G34P25) contained gelatinized cornstarch at gradual incorporation level of 30\%, $40 \%, 50 \%$, or $60 \%$, as replacement for fishmeal component of the control diet (G0P35). Final body weight and specific growth rate (SGR) were highest in fish fed control diet and diet containing 16\% of gelatinized cornstarch and $28 \%$ of protein (G16P28). Feed conversion ratio was significantly influenced by the different dietary treatments $(P<0.05)$, with higher values obtained in fish fed G31P21 diets. Protein gain and lipid gain increased with increasing dietary gelatinized cornstarch level in linking to decrease of nitrogenous losses and net energy retention indicating protein-sparing effect of gelatinized cornstarch in tilapia diet. The whole-body proximate composition was significantly affected by the different treatments. In view of the growth results and the economic evaluation, inclusion of gelatinized starch has substantially reduced the cost of feed and increased economic profitability.
\end{abstract}

\section{INTRODUCTION}

Fish is the preferred food of human nutrition because of its high content of high biological value proteins and its exceptional richness in omega-3 polyunsaturated fatty acids, vitamins, minerals, and trace elements [1].

Globally, consumption is close to $20 \mathrm{~kg} / \mathrm{capita} /$ year and aquaculture with its high growth currently supplies more than half of the demand for human consumption [2]. Tilapia is among the highest fish in the world, and its production has increased sharply in recent years [3]. World aquaculture production of tilapia Oreochromis niloticus increased to 4 million tons in 2015 [4]. Africa represents $20 \%$ of this production largely supplied by Egypt. Sub-Saharan African countries accounted for $<4 \%$ of global tilapia production [5]. Although tilapia is a native of Sub-Saharan Africa and well appreciated by the population, farming of this fish has not yet achieved sustainable economic development in these African countries.

*Corresponding Author:

B L E Mélécony Célestin,

Département Aquaculture,

Centre de Recherches Océanologiques,

BP V 18 Abidjan, Côte d'Ivoire.

Email: melecony@gmail.com
Increasing the level of aquaculture production to meet future fish demand will largely depend on the availability of quality feed at affordable prices in the quantities required, as feed accounts for 50 $80 \%$ of fish production cost [6]. Therefore, the formulation of feed that meets fish nutritional requirement is a major challenge for both commercial and farm-made feed production sectors [2]. Among feed ingredients used in the formulation of aquafeeds, fish meal remains the best source of protein. However, fish meal is still expensive and its supply contributes in part to the depletion of natural fish stocks [1]. In the next decade, the use of fishmeal in aquaculture feed will be reduced from $26 \%$ to $12 \%$ for marine fish and from $3 \%$ to $1 \%$ for tilapia followed by increased use of plant raw materials as a source of lipid and protein to replace fish oils and meal [7]. Thus, alternative protein source is explored and studied during the past decades [7]. Several plants or other invertebrate animals which contain appreciable quantity of protein with good amino acid profile have been recommended as complete or partial fish meal substitutes in fish diet [8,9]. In Fish, dietary proteins provide essential and nonessential amino acids which are the preferential nutrient used for energy production for maintenance and growth [10]. For a given raw material, it is rather the energy and nutrients they provide that are essential for fish [11]. Thus, several studies have investigated the sources of non-protein energy such as lipids and carbohydrates in fish feed. 
Carbohydrate sources such as cereals and legumes are abundant in nature and are a relatively cheaper source of energy [12]. Cereals are the most important food source in the world, both for direct human consumption, and indirectly, as inputs for animal production.

In general, the use of carbohydrate sources is more facilitated in herbivorous fish such as tilapia $O$. niloticus [13], due to their enzymatic structure which is better adapted, especially the existence of more important amylase activity [14]. Technological treatment (extrusion and gelatinization) can improve the digestibility of carbohydrates [15]. Recently, Yéo et al. [16] showed that a dietary cornstarch gelatinized at $70^{\circ} \mathrm{C}$ improves growth performance and nutrient utilization in juvenile $O$. niloticus. The aims of the present study were to investigate the effects of modulation gelatinized cornstarch/protein ratio into diet on growth performance, nutrients utilization, and body composition of fingerlings of tilapia $O$. niloticus and to determine appropriate inclusion in feed formulation for fish.

\section{MATERIALS AND METHODS}

\subsection{Experimental Rearing Conditions}

The study was conducted at the hatchery of the Center of Research for Oceanology (CRO, Abidjan, Côte d'Ivoire). 150 fingerlings of tilapia O. niloticus $(24.81 \pm 1.68 \mathrm{~g})$ were obtained from the stock of fish at the experimental aquaculture station of CRO. The fish were randomly distributed in the glass tanks of hatchery with 10 fish per tank. The fish were randomly distributed in the experimental aquaria of the hatchery with 10 fish per aquaria. Fifteen aquaria of $50 \mathrm{~L}$ containing $45 \mathrm{~L}$ of water in a closed circuit were used for this experiment. The flow of water was ensured at all times by an electric motor pump allowing a flow of $1.5 \mathrm{~L} / \mathrm{min}$. The filtration was carried out by settling, and water renewal of $30 \%$ was performed daily. Water quality was monitored throughout the study with a multiparameter (BANTE 900P) for the temperature and dissolved oxygen and $\mathrm{pH}$ meter (WTW 330) for $\mathrm{pH}$. The water temperature, $\mathrm{pH}$, and dissolved oxygen were varied between $27.08-28.57^{\circ} \mathrm{C}, 6.99-7.22$, and $6.15-6.94 \mathrm{mg} / \mathrm{L}$, respectively, and were considered favorable in fish culture tanks according to the study of Boyd [17].

\subsection{Experimental Diets and Methods}

The raw materials such as fish meal, soybean meal, wheat bran, corn, and cassava used in this study were purchased at the local market of Abidjan. All ingredients were ground to a suitable size and mixed in a commercial mixer (KENWOOD CHEF).

Five experimental diets were prepared using a kitchen meat grinder with a $3 \mathrm{~mm}$ diameter (Panasonic MK-G 1800P). A control diet (G0P35) was based on fish meal and soybean meal as protein sources. The four test diets (G16P28, G21P26, G26P23, and G34P25) contained gelatinized cornstarch at gradual incorporation level of $30 \%, 40 \%, 50 \%$, or $60 \%$, as replacement for fishmeal component of the control diet. Gelatinized cornstarch and wheat bran were used as a source of carbohydrates, and crude fish oil was used as a lipid source. The analytical composition of feed formulations is presented in Table 1.

The different diets were tested in triplicate and fed ad libitum twice daily ( $8 \mathrm{am}$ and $4 \mathrm{pm}$ ) for a period of the experimentation. Before starting the feeding trials, 40 fish sampled from aquaria were killed and kept in the freezer $\left(-20^{\circ} \mathrm{C}\right)$ for body composition analysis. The same action was repeated at the end of the experiment but with all the fish from each aquarium that was previously weighed individually.

\subsection{Chemical Analysis}

Chemical analysis of diets and fish was determined following the standard methods [18]. Calculation of the energetic content was done using the equivalent values of proteins, lipids, and carbohydrates [19].

\subsection{Zootechnical Parameters}

Daily weight gain, specific growth rate (SGR), feed conversion ratio (FCR), protein efficiency ratio (PER), protein gain (PG), lipid gain (LG), nitrogen loss (NL), net energy retention (NER), and gross energy (GE) were calculated as follows:

SGR $(\% / d)=100($ Ln final body weight [FBW]-Ln initial body weight $[\mathrm{IBW}]) / \mathrm{d}$ :

Where IBW is the IBW, FBW is the FBW, and d is the duration of the experiment (day)

FCR $=$ Dry feed consumed $(\mathrm{g}) /$ wet weight $(\mathrm{g})$

PER $=$ Wet weight gain $(\mathrm{g}) /$ protein consumed $(\mathrm{g})$

Protein or LG $(\mathrm{g} / \mathrm{kg} / \mathrm{d})$ = Final carcass nutrient (protein or lipid) contentinitial carcass nutrient (protein or lipid)

$\mathrm{GE}(\mathrm{kJ} / \mathrm{g})=22.2 \times$ protein content $+38.9 \times$ lipid content +

$17.2 \times$ carbohydrate content [19]

$\mathrm{NL}(\mathrm{g} / \mathrm{kg} / \mathrm{d})=$ nitrogen intake $(\mathrm{g} / \mathrm{kg} / \mathrm{d})$-nitrogen gain $(\mathrm{g} / \mathrm{kg} / \mathrm{d})$

NER $(\%)=[($ final body GE $)-($ initial body GE $) /$ feed consumed $\mathrm{GE}] \times 100$.

\subsection{Economic Evaluation}

The assessment of the economic cost of the diets was made on the basis of the different prices of raw materials encountered on the local market. The price of $100 \mathrm{~g}$ of diet and the quantity of feed required per diet to produce $100 \mathrm{~g}$ of weight gain was evaluated according to the following formulas:

$\mathrm{P}_{1}=\Sigma[\mathrm{R} \times \mathrm{Z} / 1000]$

where

$\mathrm{P}_{1}$ : Price of $100 \mathrm{~g}$ of feed formulated by experimental diet (F CFA)

$\mathrm{R}$ : Price of $\mathrm{kg}$ of raw materials (F CFA)

Z: Quantity of each raw material in $100 \mathrm{~g}$ of feed formulated by experimental diet $(\mathrm{g})$

$\mathrm{P}_{2}=\mathrm{FCR} \times \mathrm{P}_{1}$

$\mathrm{P}_{2}$ : Price of the quantity of feed needed to produce $100 \mathrm{~g}$ of weight gain (F CFA F)

FCR: Feed conversion ratio.

\subsection{Statistical Analysis}

Results were analyzed with analysis of variance using Statistical Version 7.1 software package. When significant, Duncan's multiple range test was used to compare differences between means. All percentage and ratio data were arcsine transformed before analysis [20]. 
Table 1: Ingredients and proximate composition of the experimental diets ( $\%$ dry weight).

\begin{tabular}{|c|c|c|c|c|c|}
\hline \multirow[t]{3}{*}{ Gelatinized cornstarch/protein ratio } & \multicolumn{5}{|c|}{ Experimental diets } \\
\hline & G0P35 & G16P28 & G21P26 & G26P24 & G31P21 \\
\hline & $0 / 35$ & $16 / 28$ & $21 / 26$ & $26 / 24$ & $31 / 21$ \\
\hline \multicolumn{6}{|l|}{ Ingredients $(\%)$} \\
\hline Fish meal & 52 & 36.4 & 31.2 & 26 & 20.8 \\
\hline Soybean meal & 18 & 18 & 18 & 18 & 18 \\
\hline Wheat bran & 20 & 20 & 20 & 20 & 20 \\
\hline Gelatinized cornstarch & 0 & 15.6 & 20.8 & 26.0 & 31.20 \\
\hline Cassava starch & 3 & 3 & 3 & 3 & 3 \\
\hline Fish oil & 5 & 5 & 5 & 5 & 5 \\
\hline Vitamin mixture $^{1}$ & 1 & 1 & 1 & 1 & 1 \\
\hline Mineral mixture ${ }^{2}$ & 1 & 1 & 1 & 1 & 1 \\
\hline \multicolumn{6}{|l|}{ Proximate composition (\%) } \\
\hline $\mathrm{DM}$ & 89.82 & 90.34 & 90.49 & 90.64 & 90.57 \\
\hline Crude protein & 35.43 & 28.34 & 26.02 & 23.67 & 21.32 \\
\hline Crude lipid & 11.1 & 9.65 & 9.28 & 8.83 & 8.37 \\
\hline Ash & 12.83 & 9.59 & 8.59 & 7.53 & 6.48 \\
\hline Crude fiber & 2.97 & 2.97 & 2.97 & 2.97 & 2.97 \\
\hline Carbohydrate & 30.07 & 44.33 & 46.10 & 53.82 & 61.53 \\
\hline Digestible energy (kJ/g diet) & 13.57 & 13.34 & 13.25 & 13.18 & 13.11 \\
\hline $\mathrm{P} / \mathrm{E}$ (mg protein/kJ diet) & 26.11 & 21.27 & 19.62 & 17.52 & 16.26 \\
\hline
\end{tabular}

\section{RESULTS AND DISCUSSION}

\subsection{Growth Performance}

During the experiment, the recorded physicochemical parameters of water were in conformity with the recommended conditions for tilapia farming $[21,22]$. Data of fish growth are reported in Table 2. Survival rates ranged from $76.67 \pm 5.77$ to $86.67 \pm 15.28 \%$ and were not significantly different between treatments $(P>0.05)$. FBW ranged from $44.75 \pm 4.65$ to $59.92 \pm 3.59 \mathrm{~g}$ and SGR from $1.63 \pm 0.13$ to 1.06 $\pm 0.13 \% \mathrm{~d}^{-1}$, with the highest values obtained in fish fed with diets G16P28 and G0P31. The difference between these two treatments for growth parameters was not significant. Several studies have shown that the digestibility of carbohydrate sources in fish can be affected by different nutritional and environmental factors [23-26]. In specific levels, dietary carbohydrates constituted an alternative source of energy for fish growth. This experiment yielded quite acceptable growth results when comparing the experimental diet G16P28 (containing $16 \%$ of gelatinized cornstarch and $28 \%$ of protein) to the control diet G0P35 (35\% of protein without gelatinized cornstarch). These results are in agreement with those of Wang et al. [27] who reported better growth in hybrid tilapia $O$. niloticus x Orecohromis aureus fed with diet containing $22 \%$ dietary starch. In O. niloticus also, Wang et al. [28] found an improvement in growth when fed a supplemented diet with $20 \%$ of starch. In other fish species, the same growth pattern related to the use of starch sources has been observed. In juvenile cobia, Rachycentron canadum, an improvement of growth performance was observed with $21.1 \%$ of dietary starch [29]. Similar effects were observed in gibel carp Carassius auratus gibelio and grass carp Ctenopharyngodon idellus fed with 30\% [30]. The juvenile yellowfin seabream Sparus latus Houttuyn also had better growth performance when fed with $20 \%$ inclusion level of raw cornstarch in the diet.

\subsection{Feed an Nutrient Utilization}

FCR was significantly different between treatments $(P<0.05)$ and the highest value was obtained in fish fed the G31P21 diet. Fish fed with control diet (G0P35) and diet G16P28 showed similar PER that ws significantly higher than those determined in fish from other treatments $(P<0.05)$. Better FCR and PER were observed in fish fed with diet G16P28 unlike other experimental diets that showed a decrease in PER. These results showed that diet G16P28 was the appropriate diet for better growth of fish. In this diet, the fishmeal in the control diet was substituted for $30 \%$ by gelatinized cornstarch, indicating that modulation of the dietary ratio with $16 \%$ of gelatinized cornstarch and $28 \%$ of protein allowed fish to better utilize the energy provided by gelatinized cornstarch for their growth. This assertion was in agreement with those of Oliva-Teles [31] which showed that energy and starch digestibility are improved with the use of dietary gelatinized starch.

PG increased with increasing gelatinized cornstarch level in diet, with the highest value recorded in fish fed with diet G31P21, containing $31 \%$ gelatinized cornstarch. Similar trend was found for $\mathrm{LG}$ responses. NLs were greater $(10.98 \pm 1.37 \mathrm{~g} / \mathrm{kg} / \mathrm{d})$ in fish fed with control diet (G0P35) and the lowest value was $6.84 \pm 0.54 \mathrm{~g} / \mathrm{kg} / \mathrm{d}$ in fish fed with G31P21 diet. NER ranged from $20.29 \pm 3.06$ to $35.04 \pm 7.41 \%$, with the highest values observed in fish received the control diet (G0P35), but this value was not statically different from those recorded with diets G16P28 and G21P26.

The inclusion of gelatinized cornstarch in diets seems to influence the nutrient utilization. PG and LG increased with increasing dietary 
gelatinized cornstarch level, and this was followed by a decrease in NER and NL. These observations were in agreement with some others studies [28,31]. Whoever contrary in this study, Oliva-Teles [31] reported a decrease in energy retention with the increase of dietary gelatinized cornstarch. The fact that PG increased with increasing dietary gelatinized cornstarch in linking to decrease of NL and NER would indicate protein-sparing effect of gelatinized cornstarch in tilapia diet as reported in previous studies [27,28].

\subsection{Whole-body Proximate Composition}

Fish whole-body protein and lipid content was significantly influenced by the different treatments [Table 3]. The maximum whole-body protein $(15.79 \pm 0.31 \%)$ was observed in fish fed with diet G21P26. The highest body lipid content $(6.16 \pm 0.49 \%)$ was obtained from fish fed with diet G31P21, containing the highest gelatinized cornstarch level $(31 \%)$, and the lowest body lipid value was recorded in fish fed with control diet (without gelatinized cornstarch). The wholebody moisture contents were inversely correlate to lipid content. Fish whole-body energy and ash level were not statically different between treatments $(P<0.05)$ [Table 3].

Whole-body protein and lipid were increased with increasing dietary gelatinized cornstarch. The increase in body lipid content related to the gelatinized cornstarch level in the diet was followed by a decrease in body moisture content. Similar results were shown with juvenile $O$. niloticus x O. aureus [27] and O. niloticus [28]. These results could be explained by the metabolic processes of the use of starch-rich diets in tilapia [28]. The authors were found an increasing whole-body protein and lipid content correlated with an increase in plasma triglyceride concentrations, total glucose cholesterol, hepatic glycogen levels, and the activities of hepatic enzymes such as glucokinase, pyruvate kinase, and lipoprotein lipase, when the fish was fed with feed containing gradual levels of cornstarch.

Body ash content was negatively related to gelatinized cornstarch level. In contrast to lipids, the body ash content was negatively correlated with the dietary gelatinized starch level. Similar results have also been reported in juvenile tilapia $O$. niloticus x O. aureus [27].

\subsection{Economic Evaluation}

Economic evaluation of the experimental diets is shown in Table 4. Compared to the control diet (G0P31), diets containing gelatinized cornstarch had the lowest costs. The lowest cost was obtained with diet G31P21 (containing 31\% gelatinized cornstarch and 21\% of protein). In terms of economic performance, fish produced with experimental feeds are more profitable.

Table 2: Growth performance and nutrient utilization of $O$. niloticus fingerlings after 56 days of feeding experimental diets.

\begin{tabular}{|c|c|c|c|c|c|}
\hline \multirow[t]{3}{*}{ Gelatinized cornstarch/protein ratio } & \multicolumn{5}{|c|}{ Experimental diets } \\
\hline & G0P35 & G16P28 & G21P26 & G26P24 & G31P21 \\
\hline & $\mathbf{0} / 35$ & $16 / 28$ & $21 / 26$ & $26 / 24$ & $31 / 21$ \\
\hline \multicolumn{6}{|l|}{ Parameters } \\
\hline IBW (g) & $24.07 \pm 1.4$ & $24.09 \pm 1.83$ & $24.63 \pm 1.16$ & $24.81 \pm 1.69$ & $24.59 \pm 1.23$ \\
\hline FBW (g) & $59.92 \pm 3.59^{\mathrm{b}}$ & $60.29 \pm 4.51^{\mathrm{b}}$ & $50.09 \pm 2.89^{\mathrm{a}}$ & $47.02 \pm 4.37^{\mathrm{a}}$ & $44.75 \pm 4.65^{\mathrm{a}}$ \\
\hline SGR (\%/d) & $1.63 \pm 0.13^{\mathrm{c}}$ & $1.60 \pm 0.06^{\mathrm{c}}$ & $1.27 \pm 0.17^{\mathrm{ab}}$ & $1.14 \pm 0.2^{\mathrm{ab}}$ & $1.06 \pm 0.13^{\mathrm{a}}$ \\
\hline FCR & $1.30 \pm 0.20^{\mathrm{a}}$ & $1.25 \pm 0.06^{\mathrm{ab}}$ & $1.39 \pm 0.22^{\mathrm{abc}}$ & $1.59 \pm 0.33^{\mathrm{bc}}$ & $1.73 \pm 0.3^{\mathrm{c}}$ \\
\hline PER & $3.55 \pm 0.73^{\mathrm{b}}$ & $3.25 \pm 0.21^{\mathrm{b}}$ & $2.18 \pm 0.36^{\mathrm{a}}$ & $2.08 \pm 0.48^{\mathrm{a}}$ & $2.41 \pm 0.39^{\mathrm{a}}$ \\
\hline$P G(g / k g / d)$ & $2.57 \pm 0.76^{\mathrm{a}}$ & $2.76 \pm 0.66^{\mathrm{a}}$ & $3.54 \pm 0.91^{\mathrm{ab}}$ & $3.51 \pm 0.55^{\mathrm{ab}}$ & $4.77 \pm 1.24^{\mathrm{b}}$ \\
\hline
\end{tabular}

Means in a row with different superscripts significantly $(P<0.05)$. IBW: Initial body weight, FBW: Final body weight, DWG: Daily weight gain, SGR: Specific growth rate, FCR: Feed conversion ratio, PER: Protein efficiency ratio, PG: Protein gain, LG: Lipid gain, NL: Nitrogen loss, NER: Net energy retention. GWG: Gestational weight gains, O. niloticus: Oreochromis niloticus.

Table 3: Whole-body composition (\% wet weight basis) of $O$. niloticus fingerlings after 56 days of feeding experimental diets.

\begin{tabular}{|c|c|c|c|c|c|c|}
\hline \multirow[t]{3}{*}{ Gelatinized cornstarch/protein ratio } & \multicolumn{6}{|c|}{ Experimental diets } \\
\hline & \multirow[t]{2}{*}{ Initial } & G0P35 & G16P28 & G21P26 & G26P24 & G31P21 \\
\hline & & $0 / 35$ & $16 / 28$ & $21 / 26$ & $26 / 24$ & $31 / 21$ \\
\hline Moisture (\%) & 75.1 & $74.37 \pm 0.32^{\mathrm{a}}$ & $73.63 \pm 0.33^{\mathrm{ab}}$ & $72.42 \pm 1.48^{\mathrm{bc}}$ & $71.98 \pm 1.44^{\mathrm{c}}$ & $69.8 \pm 0.14^{\mathrm{d}}$ \\
\hline Crude protein $(\%)$ & 13.78 & $14.25 \pm 0.28^{\mathrm{a}}$ & $15.63 \pm 0.17^{\mathrm{bc}}$ & $15.79 \pm 0.31^{\mathrm{c}}$ & $15.67 \pm 0.46^{\mathrm{bc}}$ & $14.31 \pm 0.01^{\mathrm{ab}}$ \\
\hline Crude lipid (\%) & 4.00 & $5.33 \pm 0.38^{\mathrm{a}}$ & $5.52 \pm 0.25^{\mathrm{ab}}$ & $5.62 \pm 0.02^{\mathrm{ab}}$ & $5.88 \pm 0.01^{\mathrm{ab}}$ & $6.16 \pm 0.49^{b}$ \\
\hline $\mathrm{GE}(\mathrm{kJ} / \mathrm{g})$ & 5.16 & $5.52 \pm 0.11^{\mathrm{a}}$ & $5.8 \pm 0.16^{\mathrm{a}}$ & $5.88 \pm 0.48^{\mathrm{a}}$ & $5.94 \pm 0.43^{\mathrm{a}}$ & $5.59 \pm 0.21^{\mathrm{a}}$ \\
\hline
\end{tabular}

Means in a row with different superscripts significantly $(P<0.05)$. O. niloticus: Oreochromis niloticus, GE: Gross energy. 
Table 4: Economic evaluation of experimental diets.

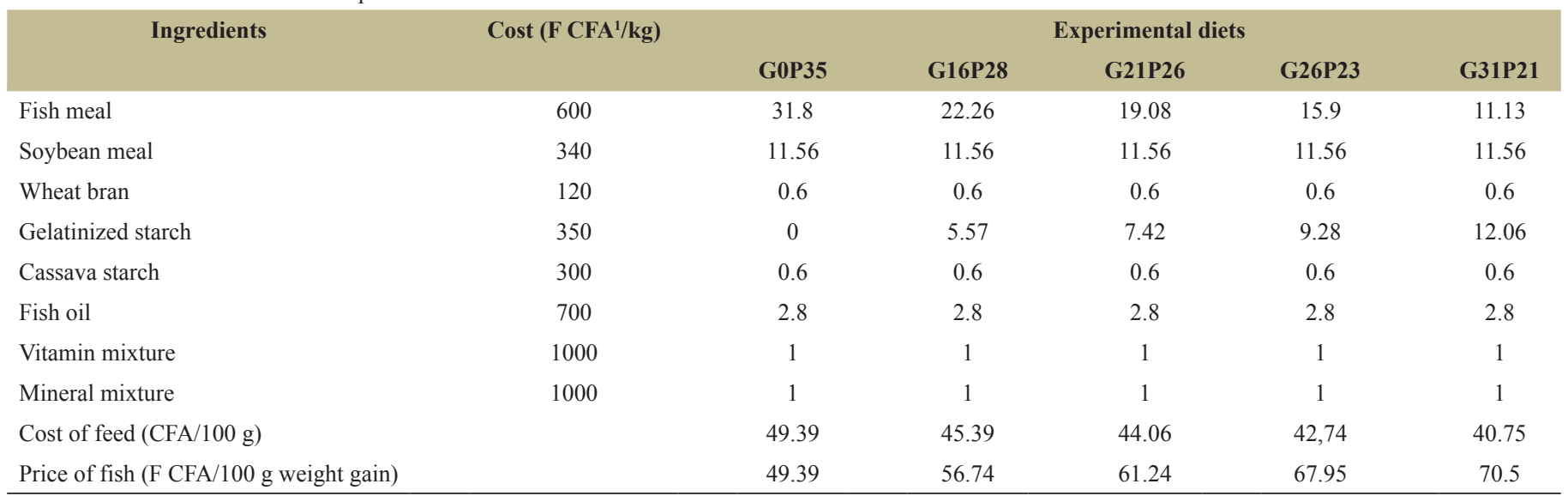

'FCFA (Franc CFA): 1 US dollar (USD) amounts to 531.17 FCFA West Africa (XOF), during the purchase of ingredients on the local market during the period of study (January-February 2016).

In view of the growth results and the economic evaluation of the experimental diets, it appeared that the diet formulated with $16 \%$ of gelatinized cornstarch and $28 \%$ of protein (G16P28) could be recommended in the practical diets for tilapia. This diet indeed allowed to obtain growth performance similar to control diet. In terms of ingredient costs, fish meal was twice more expensive than gelatinized cornstarch. Inclusion of gelatinized starch has substantially reduced the cost of feed and increased economic profitability. Similar results were obtained with the inclusion of starch in the diet of larvae of Atractosteus tropicus [32].

\section{CONCLUSION}

In this study, gelatinized cornstarch was gradually incorporated in diet of tilapia $O$. niloticus fingerlings, by modulation with protein levels. The results showed that diet formulated with $16 \%$ of gelatinized cornstarch and $28 \%$ of protein improved fish growth and nutrient utilization. The use of gelatinized starch could be recommended in practical diet of tilapias, thereby reducing the cost of diets.

\section{REFERENCES}

1. Yeo GM, Blé MC, Otchoumou KA, Dabonne S, Yao LA, Etchian AO. Digestibility and growth performance in fingerlings of tilapia Oreochromis niloticus fed with diet containing high-carbohydrate ingredients. Int J Fish Aquat Stud 2017;5:171-5.

2. FAO. The State of World Fisheries and Aquaculture 2016. Contributing to Food Security and Nutrition for all. Rome: FAO; 2016. p. 200.

3. Wang M, Lu M. Tilapia polyculture: A global review. Aquac Res 2016;47:2363-74.

4. FAO. FAO Yearbook. Fishery and Aquaculture Statistics. 2015/FAO Annuaire. Statistiques des Pêches et de L'aquaculture. 2015/FAO Anuario. Estadísticas de pesca y acuicultura. 2015. Rome/Roma, Italy/Italie/Italia: FAO; 2017. p. 78.

5. FAO. Social and economic performance of tilapia farming in Africa. In: Cai J, Quagrainie KK, Hishamunda N, editors. FAO Fisheries and Aquaculture Circular No. 1130. Rome, Italy: FAO; 2017. p. 143.

6. FAO. Aquaculture Newsletter. No. 56 (April). Rome: FAO; 2017. p. 62 .

7. Hixson SM. Fish nutrition and current issues in aquaculture: The balance in providing safe and nutritious seafood, in an environmentally sustainable manner. J Aquac Res Dev 2014;5:234.

8. Ngugi CC, Oyoo-okoth E, Manyala JO, Fitzsimmons K, Kimotho A.
Characterization of the nutritional quality of amaranth leaf protein concentrates and suitability of fish meal replacement in Nile tilapia feeds. Aquac Reports 2017;5:62-9.

9. Anvo MP, Aboua BR, Compaoré I, Sissao R, Zoungrana-Kaboré CY, Kouamelan EP, et al. Fish meal replacement by Cirina butyrospermi caterpillar's meal in pratical diets for Clarias gariepinus fingerlings. Aquac Res 2017:1-8.

10. Kim KW, Moniruzzaman M, Kim KD, Han HS, Yun H, Lee S, et al. Effects of dietary protein levels on growth performance and body composition of juvenile parrot fish, Oplegnathus fasciatus. Int Aquac Res 2016;8:239-45.

11. Médale F, Le Boucher R, Dupont-Nivet M, Quillet E, Aubain J, Panserat $\mathrm{S}$. Des aliments à base de végétaux pour les poissons d'élevage. INRA Production Animale 2013;26:303-16.

12. Tran-Duy A, Smit B, van Dam AA, Schrama JW. Effects of dietary starch and energy levels on maximum feed intake, growth and metabolism of Nile tilapia, Oreochromis niloticus. Aquaculture 2008;277:213-9.

13. Amirkolaie AK, Verreth JA, Schrama JW. Effect of gelatinization degree and inclusion level of dietary starch on the chaacteristics of digesta and faeces in Nile tilapia (Oreochromis niloticus). Aquaculture 2006;260:194-205.

14. Rocha F, Dias J, Engrola S, Gavaia P, Geurden I, Dinis MT, et al. Glucose metabolism and gene expression in juvenile zebrafish (Danio rerio) challenged with a high carbohydrate diet: effects of an acute glucose stimulus during late embryonic life. Br J Nutr 2015;113:403-13.

15. Médale F, Kaushik S. Evolution des recherches en nutrition piscicole à l'INRA: Substitution des produits d'origine marine dans l'alimentation des poissons d'élevage. INRA Prod Anim 2008;21:87-94.

16. Yéo MG, Blé MC, Babonné S, Yao LA, Otchoumou AK, Etchian AO. Effect of dietary gelatinized starch on growth performance, feed utilization and body composition of Nile tilapia (Oreochromis niloticus L.). Int J Food Sci Nutr 2017;2:125-9.

17. Boyd CE. Water Quality in Ponds for Aquaculture. Auburn, AL: Alabama Agricultural Experimental Station; 1990.

18. AOAC (Association of Official Analytical Chemists). Official Methods of Analysis. Association of Analytical Chemists. 17 ed. Washington, DC, USA: AOAC; 2000. p. 1018.

19. Luquet P, Moreau Y. Energy-protein management by some warm water fin fishes. In: Advances in tropical aquaculture, Tahiti Feb. 20-March 4 1989, AQUACOP, IFREMER. Actes Colloque 1989;9:751-5. 
20. Zar JH. Biostatistical Analysis. $2^{\text {nd }}$ ed. Englewood Cliffs, NJ: Prentice-Hall Inc.; 1984. p. 236-43.

21. Melard C. Systèmes de Production en Aquaculture. Systèmes Intensifs. Belgique; Notes de Cours, Université de Liège; 2004. p. 81.

22. Kestmont P. Zootechnie Aquacole: Reproduction et Larviculture. Namur, Belgique: Rapport, Université Notre Dame de la Paix; 2004. p. 176.

23. Hemre GI, Mommsen TP, Krogdahl A. Carbohydrates in fish nutrition: Effects on growth, glucose metabolism and hepatic enzymes. Aquac Nutr 2002;8:175-94.

24. Guerreiro I, Peres H, Castro C, Perez-Jimenez A, Castro-Cunha M, Oliva-Teles A. Water temperature does not affect protein sparing by dietary carbohydrate in Senegalese sole (Solea senegalensis) juveniles. Aquac Res 2014;45:289-98.

25. Rahman MM, Lee KJ, Lee SM. Effect of dietary carbohydrate sources on apparent nutrient digestibility of olive flounder (Paralichthys olivaceus) feed. Fish Aquat Sci 2016;19. DOI: 10.1186/s41240-0160018-815.

26. Kamalam BS, Medale F, Panserat S. Utilisation of dietary carbohydrates in farmed fishes: New insights on influencing factors, biological limitations and future strategies. Aquaculture 2017;467:3-27.

27. Wang Y, Liu YJ, Tian LX, Du ZY, Wang JT, Wang S, et al. Effects of dietary carbohydrate level on growth and body composition of juvenile tilapia, Oreochromis niloticus x O. aureus. Aquac Res 2005;36:1408-13.
28. Wang XX, Chen MY, Wang KK, Ye JD. Growth and metabolic responses in Nile tilapia (Oreochromis niloticus) subjected to varied starch and protein levels of diets. Ital J Anim Sci 2017;16:2, 308-16.

29. Ren M, Ai Q, Mai K, Ma H, Wang XX. Effect of dietary carbohydrate level on growth performance, body composition, apparent digestibility coefficient and digestive enzyme activities of juvenile cobia, Rachycentron canadum L. Aquac Res 2011;42:1467-75.

30. Li X, Zhu X, Han D, Yang Y, Jin J, Xie S. Carbohydrate utilization by herbivorous and omnivorous freshwater fish species: A comparative study on gibel carp (Carassius auratus gibelio. var CAS III) and grass carp (Ctenopharyngodon idellus). Aquac Res 2014;47:128-39.

31. Oliva-Teles A. Utilization of raw and gelatinized starch by European sea bass (Dicentrarchus labrax) juveniles. Aquaculture 2002;205:287-99.

32. Frias-Quintana CA, Álvarez-González CA, Tovar-Ramirez D, Martínez-Garcia R, Camarillo-Coop S, Pena EP, et al. Use of potato starch in diets of tropical gar (Atractosteus tropicus, Gill 1863) larvae. Fishes 2017;2:3.

\section{How to cite this article:}

Maurice YEOG, Célestin BLEM, Bédel F, Olivier EA, Soumaila D. Effects

of modulation dietary gelatinized cornstarch/protein ratio on growth

performance, feed utilization, and body composition of tilapia Oreochromis niloticus fingerlings. J App Biol Biotech. 2018;6(05):31-36.

DOI: $10.7324 / \mathrm{JABB} .2018 .60505$ 